buồng thường có lỗ sâu ở vị trí mặt bên phối hợp mặt nhai, kích thước lỗ sâu trung bình; chẩn răng ở giai đoạn I hoặc II.

\section{TÀI LIÊU THAM KHẢO}

1. Seale N.S. và Coll J.A. (2010). Vital pulp therapy for the primary dentition. Gent Dent. 58(3), $194-202$.

2. Tickotsky N., Petel R., Araki R. và CS. (2017). Caries Progression Rate In Primary Teeth: A Retrospective Study. J Clin Pediatr Dent, 41(5), 358-361.
3. Douglas A.Young và CS (2015). The American Dental Association Caries Classification System for Clinical Practice: A report of the American Dental Association Council on Scientific Affairs. The Journal of the American Dental Association. $146(2) ; 79-86$.

4. Agnleszka Bruzda-Zwiech và CS (2015) Caries Experience and Distribution by Tooth Surfaces in Primary Molars in the Pre-school Child Population of Lodz, Poland. al Health Prev DenT. $13(6) ; 557-566$.

5. Võ Trương Như Ngoc (2013). Răng trẻ em (dành cho đối tượng đại học). Nhà xuất bản Giáo dục.

\title{
KẾT QUẢ PHẪU THUÂT NộI SOI ĐIỀU TRI VIÊM KHỚP GỐI NHIỄM KHUẨN TẠI BỆNH VIỆN BẠCH MAI
}

\section{TÓM TẮT}

Mục tiêu: Đánh giá kết quả phẫu thuật nội soi điều trị viêm khớp gối nhiễm khuẩn tại Bệnh Viện Bach Mai. Đối tượng và phương pháp nghiển cứu: Nghiên cứu mô tả 57 bệnh nhân (BN) với 57 khớp gối được chẩn đoán viêm khớp gối nhiễm khuẩn, được phẫu thuật nội soi trong thời gian từ tháng 9/2018 đến hết tháng 9/2020 tai khoa Chấn thương chỉnh hình và cột sống, Bệnh viện Bạch Mai.Đánh giá kết quả sau mổ bằng thang điểm KOOS. Kết quả: Nghiên cứu có24 BN nữ (chiếm 42,1\%) và33 BN nam

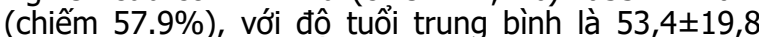
tuổi.Đánh giá kết quả sau mổ bằng thang điểm KOSS ở thời điểm sau mổ 2 tháng so với trước mổ ghi nhận: điểm KOOS triệu chứng trung bình tăng từ $42 \pm 2,87$ lên $80 \pm 2,56$, điểm KOOS đau trung bình tăng từ $42 \pm 2,87$ lên $83 \pm 2,14$, điểm KOOS chức năng, cuộc sống hàng ngày tăng từ $40 \pm 3,06$ tới $82 \pm 2,74$, điểm KOOS chức năng, hoạt động thể thao và giải trí tăng từ $24 \pm 5,56$ tới $56 \pm 5,12$ và điểm KOOS chất lượng cuộc sống tăng từ $32 \pm 3,77$ tới $79 \pm 4,01$ và điểm KOOS trung bình tăng từ $36 \pm 3,47$ tới $76 \pm 3,88$. Cải thiên điểm KOOS sau mổ 2 tháng so với trước mổ ở tất cả các phương diện có ý nghĩa thống kê với $\mathrm{p}<0,05$. Kết luận: Phẫu thuât nội soi điều tri viêm khớp gối nhiếm đem lại kết quả giảm đau tốt, cải thiên được chức năng của khớp gối và chất lượng cuộc sống cho người bênh

Tư khóa: Viêm khớp gối nhiễm khuẩn, nội soi khớp gối, Bệnh Viện Bạch Mai.

\footnotetext{
${ }^{1}$ Trường Đại học Y Hà nội

${ }^{2}$ Bênh viện Bạch Mai

Chịu trách nhiệm chính: Đào Xuân Thành

Email: daoxuanthanh@hmu.edu.vn

Ngày nhận bài: 12.5.2021

Ngày phản biên khoa học: 28.6.2021

Ngày duyệt bài: 2.7.2021
}

\section{Đào Xuân Thành ${ }^{1,2}$, Hoàng Gia $\mathrm{Du}^{2}$, Đặng Hoàng Giang ${ }^{1,2}$, Nguyễn Huy Phương ${ }^{1}$ SUMMARY \\ OUTCOMES OFARTHROSCOPIC TREATMENT FOR SEPTIC ARTHRITISOF THE KNEEIN BACH MAI HOSPITAL}

Objectives:To assess the outcomes of arthroscopic treatment for septic arthritis of the knee in Bach Mai Hospital. Subjects and Method: Descriptive study of 57 patients with 57 knee joints diagnosed septic arthritis who had arthroscopic surgery from September 2018 to September 2020 at the Department of Orthopedic \& Spine- Bach Mai Hospital. Postoperative outcomes were evaluated by the Knee injury and Osteoarthritis Outcome Score (KOOS). Results: The average age is 53.4 years with 24 female patients $(42.1 \%)$ and 33 male patients $(57.9 \%)$. Symptoms KOOS score increased from $42 \pm$ 2.87 before surgery to $80 \pm 2.562$-month after surgery. Pain KOOS score increased from $42 \pm 2.87$ to $83 \pm 2.14$. Function in daily living (ADL) KOOS score increased from $40 \pm 3.06$ to $82 \pm 2.74$. Function in Sport and Recreation (Sport/Rec) KOOS score increased from $24 \pm 5.56$ to $56 \pm 5.12$. Quality of Life (QoL) KOOS score increased from $32 \pm 3.77$ to $79 \pm$ 4.01. Average KOOS score increased from $36 \pm 3.47$ before surgery to $76 \pm 3.88$ 2-month after surgery. Conclusion: Arthroscopic treatment for septic arthritis of the knee is an effective method, results in improving the severity of pain, patient's knee function and quality of life.

Keywords: Septic arthritis, Bach Mai Hospital, knee arthroscopy

\section{I. ĐĂT VẤN ĐỀ}

Viêm khớp nhiễm khuẩn là bệnh viêm khớp do vi khuẩn có mặt trong khớp và trực tiếp gây bệnh. Viêm khớp gối nhiễm khuẩn là bệnh lý nhiễm khuẩn khớp thường gặp nhất và thường để lại nhiều di chứng xấu đến chức năng 
khớp[1]. Vi khuẩn Gram dương là tác nhân gây bệnh chủ yếu, chiếm tỷ lệ $65-85 \%$; vi khuẩn Gram âm ít gặp hơn, chỉ chiếm $10-20 \%$ các trường hợp [2].

Sử dụng kháng sinh đường toàn thân kết hợp với dẫn lưu mủ khỏi ổ khớp là 2 biện pháp chính trong điều trị viêm khớp gối nhiếm khuẩn. Để dẫn lưu mủ khớp gối, trước kia thường mổ mở hoặc chọc hút khớp gối qua da. Với sự tiến bộ của phẫu thuật nội soi khớp nói chung và nội soi khớp gối nói riêng, phẫu thuật nội soi đã trở thành một biện pháp chính để dẫn lưu mủ khớp gối. Phẫu thuật nội soi khớp gối là một phẫu thuật ít xâm lẩn, qua đó phẫu thuật viên có thể lây bệnh phẩm trực tiếp từ trong khớp gối để đem cây khuẩn và làm kháng sinh đồ, cắt lọc tổ chức viêm nhiễm và hoại tử, bơm rửa sạch ổ khớp có kiểm soát, đem lại hiệu quả điều trị tích cực cho người bệnh [3]. Mặc dù phẫu thuật nội soi khớp được ứng dụng rất rộng rãi trong điều trị viêm khớp nhiễm khuẩn, đặc biệt là viêm khớp gối nhiểm khuẩn nhưng cho đến nay, theo hiểu biết của chúng tôi, có rất ít công trình nghiên cứu đánh giá hiệu quả của phẫu thuật nội soi khớp gối trong điều trị viêm khớp gối nhiễm khuẩn. Bởi vậy, chúng tôi tiến hành nghiên cứu đề tài này nhằm mục tiêu đánh giá kết quả phẫu thuật nội soi điều trị viêm khớp gối nhiễm khuẩn tại Bệnh viện Bạch Mai.

\section{II. ĐỐI TƯợNG VÀ PHƯƠNG PHÁP NGHIÊN CỨU}

2.1.Đổi tượng nghiên cứu. Tất cả các bệnh nhân viêm khớp gối nhiễm khuẩn được chẩn đoán và điều trị phẫu thuật nội soi khớp gối tại Khoa Chấn thương chỉnh hình và cột sống, Bệnh viện Bạch Mai từ tháng 9/2018 đển hết tháng 9/2020.

\section{Tiêu chuẩn lựa chọn bệnh nhân}

- BN được chẩn đoán viêm khớp gối nhiễm khuẩn trước phẫu thuật nội soi khớp gối dựa vào các tiêu chuẩn sau:

Lâm sàng: Có ít nhất một trong các biểu hiện: thân nhiệt $\geq 38,5^{\circ} \mathrm{C}$; sưng, nóng, đỏ đau tại khớp gối; tràn dịch khớp gối.

Cận lâm sàng có các tiêu chuẩn sau:

(1)Tăng số lượng bạch cầu (bạch cầu $\geq$ $10000 / \mathrm{ml}$, bạch cầu đa nhân trung tính > 75\%); tăng tốc độ máu lắng (Máu lắng giờ thứ nhất > và máu lắng giờ thứ hai>) và tăng nồng độ protein phản ứng $\mathrm{C}(\mathrm{CRP}>)$.

(2)Có bằng chứng tràn dịch khớp gối trên siêu âm và cộng hưởng từ khớp gối.

(3)Có bằng chứng nhiễm khuẩn tại khớp gối: Chọc hút dịch khớp gối làm tế bào có số lượng bạch cầu >50000 bạch câu/ ml và/ hoặccấy vi khuẩn dịch khớp gối tìm được vi khuẩn.

- Bệnh nhân được phẫu thuật nội soi khớp gối để điều trị, khám và theo dõi định kỳ sau mổ theo hẹn.

Tiêu chuẩn loại trừ:

- Viêm khớp gối nhiểm khuẩn trong tình trạng nhiễm khuẩn nặng (nhiễm khuẩn huyết hoặc sốc nhiễm khuẩn) đe dọa tính mạng.

- Viêm nhiều khớp nhiễm khuẩn trong đó có khớp không phải khớp gối.

2.2. Phương pháp nghiên cứu. Nghiên cứuthuần tập mô tả tiến cứu.

2.3 Các chỉ số nghiên cứu. Các chỉ số nghiên cứu về đặc điểm chung của nhóm nghiên cứu bao gồm: tuổi, giới, bệnh lý nội khoa kèm theo, đường vào của vi khuẩn, kết quả cấy dịch khớp gối.

Đánh giá kết quả điều trị bao gồm: Đánh giá diễn biến của số lượng bạch cầu, máu lắng, CRP trước mổ và sau mổ ở các thời điểm sau mổ 1 tuần, sau mổ 1 tháng, sau mổ 2 tháng. Đánh giá chức năng khớp gối trước mổ và sau mổ 2 tháng dựa vào thang điểm Knee injury and Osteoarthritis Outcome Score (KOOS). Thang điểm này được thiết kế để đánh giá kết quả ngắn hạn và dài hạn của thương tổn khớp gối. Thang điểm KOOS đánh giá trên 5 khía cạnh riêng biệt: đau (9 câu hỏi), triệu chứng (7 câu hỏi), hoạt động sinh hoạt hàng ngày (17 câu hỏi), chức năng thể thao và giải trí ( 5 câu hỏi), chất lượng cuộc sống (4 câu hỏi).Thang điểm Likert 5 bậc được sử dụng và mối câu hỏi có 5 lựa chọn có thể đánh giá, từ 0 (không vấn đề) đến 4 (vấn đề rất nghiêm trọng). Xác định số điểm đạt được của người bênh ở tất cả các câu trả lời của mỗi khía cạnh. Điểm của mỗi khía canh được chuyển đổi sang thang điểm từ 0-100 bằng cáchxác định phần trăm số điểm của người bệnh đạt được trên tổng số điểm cao nhất có thể đạt được ở khía cạnh đó.

2.4. Phân tích số liệu: Số liệu được nhập liệu và phân tích bằng phần mềm SPSS 20.0. Các biến định lượng được trình bày dưới dang trung bình và độ lệch chuẩn, được kiểm định bằng phép kiểm định $T$ hoặc $U$ Mann Whitney. Các biến định tính được trình bày dưới dạng tỷ lệ và được kiểm định bằng kiểm định Khi bình phương hoặc Fisher.

\section{KẾT QUẢ NGHIÊN CỨU 3.1 Các đặc điểm chung của nhóm nghiên cứu \\ - Nghiên cứu được tiến hành ở 57 bệnh nhân}


với 57 khớp gối được chẩn đoán viêm khớp gối nhiễm khuẩn bao gồm 33 nam $(57,9 \%)$ và 24 nữ (42,1\%). Tuổi trung bình của bệnh nhân trong nhóm nghiên cứu là 53,4 $\pm 19,8$ (tuổi).

- Bệnh nhân có ít nhất một bệnh lý nội khoa kèm theo chiếm $63,2 \%$, trong đó: viêm khớp dạng thấp $(63,2 \%)$; tăng huyết áp $(45,6 \%)$; đái tháo đường $(26,3 \%)$; dùng corticoid kéo dài $(21,1 \%)$; bệnh gout $(8,8 \%)$; nghiện rượu (7,0\%). Bệnh nhân không có bệnh lý nội khoa kèm theo chiếm tỷ lệ 36,8\%.

- Đường vào của vi khuẩn được xác định: sau chấn thương gối được điều trị tại y tế cơ sở trước đó có 25 bệnh nhân (43,8\%), do đường máu có 20 bệnh nhẩn (35,2\%), sau chọc hút dịch và tiêm khớp gối có 11 bệnh nhân (19,3\%) và sau mổ vết thương khớp gối có 1 bệnh nhân (1,7\%).

-Kết quả cấy dịch khớp gối: 50 bệnh nhân (chiếm tỷ lệ $87,7 \%$ ) có vi khuẩn trong đó 42 bệnh nhân $(73,7 \%)$ có kết quả là vi khuẩn Gram dương, 8 bệnh nhân $(14,0 \%)$ có vi khuẩn Gram âm và 7 bệnh nhân (chiếm tỷ lệ 12,3\%) không xác định được vi khuẩn gây bệnh.

\subsection{Kết quả điêu trị}

- Cải thiện các chỉ số xét nghiệm phản ánh tình trạng viêm khớp gối.

Bảng 1: Cải thiện chi số xét nghiệm phản ánh tình trạng viêm khớp gối

\begin{tabular}{|c|c|c|c|c|}
\hline & \multirow{2}{*}{ Trước mổ } & \multicolumn{3}{|c|}{ Sau mố } \\
\cline { 3 - 5 } & & 1 tuần & 1 tháng & 2 tháng \\
\hline Số lượng bạch cầu $(\mathrm{G} / \mathrm{l})$ & $10,65 \pm 2,13$ & $9,54 \pm 1,13$ & $8,95 \pm 2,07$ & $8,67 \pm 1,95$ \\
\hline Máu lắng giờ $1(\mathrm{~mm})$ & $17,73 \pm 2,06$ & $16,25 \pm 3,05$ & $15,15 \pm 3,54$ & $13,11 \pm 3,86$ \\
\hline Máu lắng giờ 2 $(\mathrm{mm})$ & $24,68 \pm 3,78$ & $23,97 \pm 3,67$ & $21,84 \pm 3,87$ & $16,34 \pm 3,56$ \\
\hline Nồng độ CRP $(\mathrm{mg} / \mathrm{dl})$ & $6,57 \pm 0,43$ & $0,85 \pm 0,09$ & $0,79 \pm 0,12$ & $0,84 \pm 0,08$ \\
\hline
\end{tabular}

- Cải thiện chức năng khớp gối đánh giá theo thang điểm KOOS

Bảng 2: Cải thiện chức năng khớp gối theo KOOS sau mổ 2 tháng

\begin{tabular}{|c|c|c|c|}
\hline $\begin{array}{c}\text { Chức năng khớp gối } \\
\text { đánh giá theo thang điểm KoOS }\end{array}$ & Trước mổ & Sau mổ $\mathbf{2}$ tháng & p \\
\hline Triệu chứng & $42 \pm 2,87$ & $80 \pm 2,56$ & $<0,05$ \\
\hline Đau & $42 \pm 2,87$ & $83 \pm 2,14$ & $<0,05$ \\
\hline Chức năng, cuộc sống hàng ngày & $40 \pm 3,06$ & $82 \pm 2,74$ & $<0,05$ \\
\hline Chức năng, hoạt động thể thao và giải trí & $24 \pm 5,56$ & $56 \pm 5,12$ & $<0,05$ \\
\hline Chất lượng cuộc sống & $32 \pm 3,77$ & $79 \pm 4,01$ & $<0,05$ \\
\hline Trung bình chung & $36 \pm 3,47$ & $76 \pm 3,88$ & $<0,05$ \\
\hline
\end{tabular}

\section{BÀN LUẬN}

Viêm khớpnhiễm khuẩn là bệnh lý ít gặp, tỷ lệ hiện mắc trong cộng đồng ở các nước phát triểnkhoảng 2-10 trường hợp/100 000 dân mỗi năm và có xu hướng tăng lên trong những năm gần đây. Tỷ lệ hiện mắc của viêm khớp gối nhiễm khuẩn ở các nước đang phát triển hiện vẫn còn chưa rõ. Viêm khớp gối nhiễm khuẩn là bệnh lý viêm khớp nhiễm khuẩn thường gặp nhất, chiếm khoảng $50 \%$ tổng số các bệnh viêm khớp nhiễm khuẩn. Bệnh thường gặp ở những người có yếu tố nguy cơ cao bao gồm: trên 60 tuổi, có tình trạng nhiễm khuẩn huyết hoặc vãng khuẩn huyết gần đây, đang điều trị hóa trị hoặc xạ trị, đái tháo đường, xơ gan, bệnh thận mạn tính, chọc hút dịch khớp hoặc tiêm khớp gối, sử dụng cortisol kéo dài, thực hiện phẫu thuật khớp gối. Viêm khớp dang thấp làm tăng nguy cơ viêm khớp gối nhiếm khuẩn gấp 4-15 lần so với cộng đồng.Đường vào của viêm khớp gối nhiễm khuẩn có thể do đường máu, xâm nhập trực tiếp, do xâm nhập từ ổ nhiễm khuẩn cạnh gối hoặc do thầy thuốc gây nên trong đó viêm khớp gối nhiễm khuẩn do đường máu thường gặp nhất. Vi khuẩn gây bệnh thường gặp là tụ cầu vàng, tiếp đến là liên câu và các vi khuẩngram dương khác; viêm khớp gối do vi khuẩn gram âm chiếm khoảng $20-25 \%$ các trường hợp và viêm khớp gối do đa vi khuẩn chiếm khoảng $5 \%$ các trường hợp [2].

Điều trị viêm khớp gối nhiễm khuẩn cần kết hợp giữa kháng sinh đường toàn thân và dẫn lưu mủ khớp gối. Kháng sinh cần được điều trị sớm ngay sau khi có chẩn đoán xác định. Khi chưa có kháng sinh đồ thì dùng kháng sinh theo ý kiến chuyên gia, khi đã có kháng sinh đồ cần dùng kháng sinh theo kháng sinh đồ. Vài phương pháp dẫn lưu mủ khớp gối được đề cập bao gồm chọc hút dịch khớp gối qua da, mổ mở dẫn lưu mủ khớp gối và mổ nội soi dẫn lưu mủ khớp gối. Ngày nay nhiều tác giả ủng hộ phẫu thuật nội soi trong điều trị viêm mủ khớp nói chung và viêm mủ khớp gối nói riêng so với mổ mở hay chọc hút dịch khớp gối [3], [4], [5]. Phẫu thuật nội soi khớp gối có thể lấy bệnh phẩm để cẩy khuẩn và làm mô bệnh học; đánh giá và phân 
loại giai đoạn viêm mủ khớp theo phân loại của Gächter, cắt lọc tổ chức hoạt dịch hoại tử, bơm rửa sạch ổ khớp [6]. Ivey và Clark báo cáo một trong những nghiên cứu tiến cứu đầu tiên đánh giá hiệu quả của nội soi khớp gối điều trị viêm khớp gối nhiễm khuẩn ở 10 bệnh nhân với 11 khớp gối ghi nhận không trường hợp nào phải mổ lại lần thứ hai và tất cả các trường hợp đều có chức năng khớp gối trở lại bình thường như trước khi bị viêm khớp gối nhiễm khuẩn [7]. Balabaud và cộng sự nghiên cứu thuần tập 40 trường hợp viêm khớp gối nhiễm khuẩn, trong đó 21 trường hợp được mổ nội soi và 19 trường hợp được mổ mở dẩn lưu mủ khớp gối cũng đồng ý với các nhận định của các tác giả trước đó là có mối tương quan có ý nghĩa thống kê giữa phân loại giai đoạn viêm khớp gối nhiễm khuẩn của Gä̉chter với chức năng khớp gối. Từ những kết quả thu được từ nghiên cứu tác giả khuyến cáo nên sử dụng phẫu thuật nội soi khớp gối là một biện pháp điều trị thường quy trong điều trị viêm khớp gối nhiễm khuẩn [8]. Trong nghiên cứu của chúng tôi chúng tôi ghi nhận sự cải thiện rõ rệt về tình trạng viêm cũng như chức năng khớp gối đánh giá theo thang điểm KOOS. Sự thay đổi số lượng bạch cầu và nồng độ protein phản ứng $C$ sau mổ 1 tuần có ý nghĩa thống kê so với trước mổ, phản ánh tình trang viêm được cải thiện một cách có ý nghĩa thống kê ở thời điểm trước mổ so với sau mổ và kết quả điều trị này được duy trì ở tháng thứ nhất và tháng thứ hai sau mổ. Cùng phản ánh tình trang viêm nhưng tốc độ máu lắng giờ thứ nhất và giờ thứ hai cải thiện chậm hớn trong thời gian 2 tháng sau mổ so với trước mổ. Điều này hoàn toàn phù hợp với bệnh học viêm khớp gối nhiễm khuẩn. Chức năng khớp gối cũng được cải thiện rõ rệt sau mổ ở tất cả các khía cạnh của thang điểm KOOS cũng như điểm KOOS trung bình chung, có ý nghĩa thống kê với $p<0,05$. Điều này khẳng định triệu chứng của khớp gối, chức năng khớp gối và chất lượng cuộc sống của người bệnh đều được cải thiện đáng kể sau mổ.

Mặc dù phẫu thuật nội soi rất hiệu quả trong điêu trị viêm khớp nhiếm khuẩn nhưng một số trường hợp vẫn có tình trạng viêm khớp nhiếm khuẩn tái diễn. Có những người bệnh cần phẫu thuật nội soi vài lần để làm sạch ổ khớp. Yếu tố tiên lượng số lần phẫu thuật theo Vispo Seara J.L và cộng sự là kinh nghiệm mổ nội soi khớp của phẫu thuật viên, thời gian từ khi khởi phát triệu chứng cho đến khi mổ và loại vi khuẩn gây bệnh [9]. Hunter và cộng sự theo dõi 132 khớp bị viêm nhiếm khuẩn ở 128 người bệnh được mổ nội soi để điều trị nhận thây có 49 bệnh nhân (38\%) cần phải nội soi lần tiếp theo. Các yếu tô tiên lượng tình trạng nhiễm trùng tái diến bao gồm tiền sử bệnh lý viêm màng hoạt dịch khớp gối, khớp lớn (khớp háng, khớp vai, khớp gối), tễ bào bạch câu dịch khớp > 85.000/ml, cây vi khuẩn dịch khớp tìm ra tụ cầu vàng và đái tháo đường. Theo hiểu biết của chúng tôi, trong viêm khớp gối nhiễm khuẩn chưa có những báo cáo theo dõi lâu dài và tìm ra yếu tố tiên lượng tình trạng nhiếm trùng tái diễn sau mổ.

\section{KẾT LUẬN}

Phẫu thuật thay nội soi điều trị viêm khớp gối nhiễm khuẩn đã giải quyết tốt tình trạng nhiểm trùng tại khớp gối, cải thiện triệu chứng và chức năng khớp gối, cải thiện chất lượng cuộc sống cho người bệnh.

\section{TÀI LIẸU THAM KHẢO}

1. Joseph G Elsissy, Joseph $\mathbf{N}$ Liu, Peter J Wilton, Ikenna Nwachuku, Anirudh K Gowd, Nirav H Amin. Bacterial Septic Arthritis of the Adult Native Knee Joint: A Review, JBJS Rev 2020 Jan; 8(1): e0059.

2. Shirtliff ME, Mader JT. Acute septic arthritis. Clin Microbiol Rev. 2002 Oct;15(4):527-44.

3. Peres LR, Marchitto RO, Pereira GS, Yoshino FS, de Castro Fernandes $M$, Matsumoto $\mathrm{MH}$. Arthrotomy versus arthroscopy in the treatment of septic arthritis of the knee in adults: a randomized clinical trial. Knee Surg Sports Traumatol Arthrosc. 2016 Oct;24(10): 3155-62. Epub 2015 Dec 24. 16.

4. Bohler $C$, Dragana $M$, Puchner $S$, Windhager . R, Holinka J. Treatment of septic arthritis of the knee: a comparison between arthroscopy and arthrotomy. Knee Surg Sports Traumatol Arthrosc. 2016 Oct;24(10):3147-54. Epub 2015 May 28.

5. A"im F, Delambre J, Bauer T, Hardy P. Efficacy of arthroscopic treatment for resolving infection in septic arthritis of native joints. Orthop Traumatol Surg Res. 2015 Feb;101(1): 61-4. Epub 2015 Jan 23.

6. Stutz G, Kuster MS, Kleinstu“ ck F, Ga“chter A. Arthroscopic management of septic arthritis: stages of infection and results. Knee Surg Sports Traumatol Arthrosc. 2000; 8:270-274.

7. Ivey M, Clark R. Arthroscopic debridement of the knee for septic arthritis. Clin Orthop Relat Res. 1985 Oct; 199:201-6.

8. Balabaud L, Gaudias J, Boeri C, Jenny JY, Kehr P. Results of treatment of septic knee arthritis: a retrospective series of 40 cases. Knee Surg Sports Traumatol Arthrosc. 2007 Apr;15(4): 387-92. Epub 2006 Dec 6.

9. Vispo Seara JL, Barthel T, et al. Arthroscopic treatment of septic joints: prognostic factors, Arch Orthop Trauma Surg. 2002; 122: $204-211$. 